\title{
Effects of Testosterone and Estradiol on Serum Somatomedin A and Growth Rate of Rats
}

\author{
KoIchi KAWAI, Etsuro OGATA*, Kazue TAKANO**, \\ NAOMI HIZUKA**, KAMEJIRO YAMASHITA AND \\ KAZUO SHIZUME** \\ Division of Endocrinology and Metabolism, The Institute of Clinical \\ Medicine, The University of Tsukuba, Niihari-gun, Ibaraki-ken \\ * The Fourth Department of Medicine, University of Tokyo, Tokyo \\ **Department of Internal Medicine, Tokyo Women's Medical College, \\ Shinjuku-ku, Tokyo
}

\begin{abstract}
The mode of involvement of sex steroids in the growth spurt during adolescence was studied in Wistar rats with a special reference to the level of serum somatomedin A (SMA) determined by radioreceptor assay. Intramuscular administration of testosterone propionate $(\mathrm{T} ; 1 \mathrm{mg} / \mathrm{day}$, alternately for 10 days) to female or gonadectomized male rats provoked a small but significant increase in their body weight or body length without affecting the serum SMA level. In contrast, in hypophysectomized (hypox) male rats $\mathbf{T}$ caused a considerable increase in body weight and the serum SMA level only when administered concurrently with bovine growth hormone (bGH; $0.2 \mathrm{U} / \mathrm{day}$, ip). $\mathrm{T}$ did not affect the sulfation activity in vitro. These results suggest that androgen participates in the growth spurt during adolescence by enhancing the SMA effect and/or potentiating the SMA production by $\mathrm{GH}$.

Estradiol benzoate $\left(\mathrm{E}_{2} ; 100 \mu \mathrm{g} /\right.$ day, alternately for 10 days) caused a decrease in the serum SMA level and the growth rate in normal male rats. However, $\mathrm{E}_{2}$ produced an increase in the SMA level when administered to hypox male rats, although the growth was retarded and sulfation potency of the serum was sharply reduced. These results indicate that $E_{2}$ may suppress the growth by lowering SMA generation in normal rats and cause a production of biologically inactive SMA in hypox male rats.
\end{abstract}

Although growth hormone $(\mathrm{GH})$ plays a major role in the stimulation of the growth of bone, skeletal muscle and several other tissues, it is also possible that hormones of the thyroid, parathyroids, adrenals, gonads and pancreatic islets are involved in the growth (Daughaday et al., 1975). The marked pubertal increase in the growth velocity has been ascribed to the concurrent enhancement of the secretion of sex steroids in addition to sustained GH secretion (Daughaday et al., 1975). Testosterone

Received March 29, 1982 was shown in animals to interact with submaximal doses of $\mathrm{GH}$ in increasing epiphysial cartilage growth (Geschwind and Li, 1955). On the other hand, pharmacological doses of estrogens have been reported to retard the skeletal growth both in man and in animals (Almqvist et al., 1961; Berntsen, 1968).

It is established that the growth-promoting effect of GH on the skeletal system is mediated by somatomedins (Daughaday et al., 1972). Therefore, elucidation of the relationship between somatomedins and sex steroids appears crucial for understanding the influence of sex 
steroids on the growth response. Although several papers have already dealt with this problem by using the bioassay of somatomedin activity, the relationship between the growth spurt, gonadal activity and the serum somatomedin level remains yet to be settled. The uncertainty appears to stem in part from the poor reliability of available bioassay systems for somatomedins. The assay suffers from serious interference by several serum constituents, for example free fatty acids and glucocorticoids (Eisenbarth et al., 1973). The radioreceptor assay (RRA) is an alternate and is considered more specific in measuring somatomedins in serum.

In the present study, the effects of gonadal steroids were examined in rats in terms of the growth rate and of the serum somatomedin activity by RRA and bioassay. The in vitro action of steroids on somatomedin bioassay was also studied. From these experiments, it was shown that testosterone stimulated the skeletal growth mainly by potentiating the effect of SMA. Estradiol, on the other hand, caused an inhibition of growth by diminishing the SMA production or by producing abnormal SMA in the presence or absence of the pituitary, respectively.

\section{Materials and Methods}

\section{Materials:}

Testosterone propionate in sesame oil (ENARMON), estradiol benzoate in water suspension (OVAHORMON) and the respective vehicles were kindly donated by Teikokuzoki Co. (Tokyo). Testosterone propionate and estradiol benzoate used in in vitro experiment were purchased from Sigma (St. Louis, MO). Bovine GH was supplied from the National Pituitary Agency (NIH-GH-B18, The biological activity is $0.8 \mathrm{IU} / \mathrm{mg}$ ). It was dissolved in a slightly alkaline solution of $0.9 \% \mathrm{NaCl}$ at a concentration of $2.5 \mathrm{mg} / \mathrm{ml}$. Radioactive sulfate $\left({ }^{35} \mathrm{~S}\right)$ was obtained from the Radiochemical Center (Amersham, UK).

Animals:

Wistar strain rats of both sexes were used. They were fed ad libitum with a standard laboratory rat chow (Oriental Yeast Industry Co. Tokyo) and tap
EXPERIMENTAL PROTOCOL

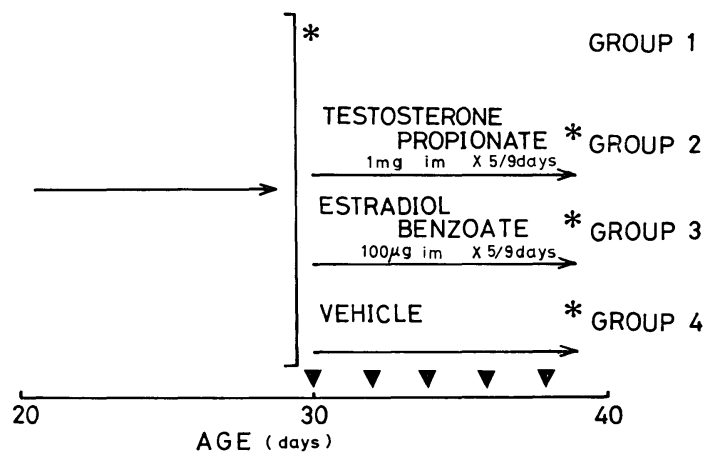

Fig. 1. * and $\boldsymbol{\nabla}$ indicate the day when sacrificed and injected, respectivity.

water. Some rats underwent transaural hypohysectomy at 21 days of age. They were used when hypopituitarism was confirmed by growth retardation. As shown in Fig. 1, the animals were randomly allocated into four groups at the age of 25 days (the number of each group is described in the figures and tables). From 30 through 39 days, they received $1 \mathrm{mg}$ of testosterone propionate ( $\mathrm{T}), 100 \mu \mathrm{g}$ of estradiol benzoate $\left(E_{2}\right)$ or vehicle of $\mathrm{T}$ im on alternate days (5 times). Some of the hypox rats concurrently received $0.2 \mathrm{U}$ bGH ip every day. Twenty four hours after the last injection, under anesthesia with pentobarbital the body weight and length (nose to tail tip) were measured and the blood was withdrawn from the abdominal aorta. In group 1, the above procedures were performed at 30 days of age. Serum was separated and kept frozen at $-70^{\circ} \mathrm{C}$ until assay.

\section{Radioreceptor assay of SMA:}

Rat serum SMA was determined by a radioreceptor assay (Takano et al., 1975). Pooled serum from two healthy males and two healthy females ages between 20 and 25 was used as an arbitrary reference. One unit (U) of SMA is arbitrarily defined as the SMA content in $1 \mathrm{ml}$ of this pooled serum. The data are presented on this arbitrary unit.

\section{Bioassay of somatomedins:}

Sulfation activity of the rat serum was measured with embryonic chick cartilage using a slight modification of the method by Hall (1970) as described previously (Kawai and Ogata, 1981). Half pelvic cartilage from 12-day-old chick embryo was added to the tube containing $1 \mathrm{ml}$ of the assay mixture which consisted of the Minimum Essential Medium with Hank's salts (GIBCO, U.S.A.) supplemented with $150 \mu \mathrm{g}$ glutamine, $100 \mu \mathrm{g}$ kanamycin, $30 \mathrm{IU}$ of penicillin, $0.2 \mu \mathrm{Ci}$ of carrier-free ${ }^{35} \mathrm{~S}$-sulfate and serum. Serum was added in 
final concentrations of $5 \%$ and $20 \%$ for a four point assay. Following the incubation the cartilage was boiled for $10 \mathrm{~min}$, placed in saturated $\mathrm{Na}_{2} \mathrm{SO}_{4}$ for $3 \mathrm{hr}$ and then rinsed with distilled water. The cartilage was solubilized in a scintillation vial with $1 \mathrm{ml}$ of $0.5 \mathrm{~N}$ quarternary ammonium hydroxide in toluene (Soluene350, from Packard, U.S.A.) and diluted with $9 \mathrm{ml}$ of toluene-Triton X-100 $(2: 1, \mathrm{~V} / \mathrm{V})$ containing $0.4 \% 2,5$ diphenyloxazole (PPO) and $0.008 \%$ 1.4-bis[2-(5phenyloxazyol)] benzene (POPOP) (Dry Blend 1, from Eastman, U.S.A.). Radioactivity was measured in a liquid scintillation spectrometer (Packard). The samples were analysed in quadruplicate. One unit is arbitrarily defined as the sulfation activity in $1 \mathrm{ml}$ of the pooled normal human serum described above.

Serum estradiol and testosterone levels were determined with CIS-radioimmunoassay kits (Green-Cross Co. Tokyo).

Statistical analysis of results was carried out using Student's $t$ test. Results were compared only among groups of animals from the same batch. Mean values were expressed as mean $\pm \mathrm{SEM}$.

\section{Results}

\section{Changes in serum SMA with aging}

The body length and the serum SMA content were examined in male rats as function of age. The growth spurt was recognized following the onset of puberty beginning at about 4 weeks of age. The SMA increased in rough correlation with the increase in body length (Fig. 2).

Effect of sex steroids on serum SMA and growth of normal male rats

As shown in Table 1, administration im of $\mathrm{T}(1 \mathrm{mg} /$ day, alternately for 10 days) tended to increase the serum SMA and the body weight although statistically not significant.

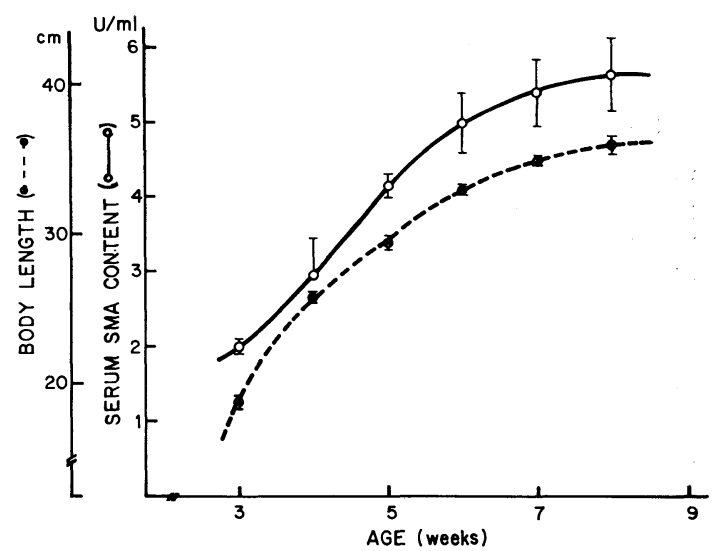

Fig. 2. Increase in the body length and serum SMA level of the rat following the onset of puberty. Under ether anesthesia, the body length (nose to tail tip) was measured and the blood was withdrawn by heart puncture. The change was studied in the bled rat. Values are mean $\pm \operatorname{SEM}(n=4-6)$.

The serum testosterone contents of the T group and the vehicle group were $3.6 \mathrm{ng} / \mathrm{ml}$ and 0.284 $\mathrm{ng} / \mathrm{ml}$, respectively (by radioimmunoassay). Administration im of $\mathrm{E}_{2}(100 \mu \mathrm{g} / \mathrm{day}$, alternately for 10 days) diminished the increase in body weight, length and food intake. The agerelated increase in the serum SMA was also suppressed. The effects of vehicles for both $\mathrm{T}$ and $\mathrm{E}_{2}$ were compared in a preceeding series of experiments. They showed no significant difference. Therefore, only the vehicle of $\mathrm{T}$ was examined as a control. Serum $\mathrm{E}_{2}$ content of the $E_{2}$ group and the vehicle group was $294 \mathrm{pg} / \mathrm{ml}$ and $15.6 \mathrm{pg} / \mathrm{ml}$, respectively (by radioimmunoassay). Smaller doses of $\mathrm{T}$ (10

Table 1. Effect of sex steroids on growth of normal male rat and serum SMA levels.

\begin{tabular}{lccccc}
\hline \multicolumn{1}{c}{ Groups } & No. & $\begin{array}{c}\text { SMA } \\
(\mathrm{U} / \mathrm{ml})\end{array}$ & $\begin{array}{c}\text { Body length } \\
(\mathrm{cm})\end{array}$ & $\begin{array}{c}\text { Body weight } \\
(\mathrm{g})\end{array}$ & $\begin{array}{c}\text { Food intake } \\
(\mathrm{g} / \mathrm{day} / \mathrm{rat})\end{array}$ \\
\hline $\begin{array}{l}\text { Before } \\
\text { Testosterone propionate } \\
\quad(1 \mathrm{mg} / \text { day })\end{array}$ & 5 & $1.94 \pm 0.02$ & $28.4 \pm 0.3$ & $132 \pm 4$ & $11.8 \pm 2.2$ \\
$\quad \begin{array}{l}\text { Estradiol benzoate } \\
\quad(100 \mu \mathrm{g} / \text { day) }\end{array}$ & 5 & $4.81 \pm 0.40^{\mathrm{a}}$ & $32.9 \pm 0.3^{\mathrm{a}}$ & $181 \pm 3^{\mathrm{a}}$ & $14.9 \pm 1.0^{\mathrm{a}}$ \\
Vehicle & 5 & $2.45 \pm 0.30^{\mathrm{b}}$ & $30.5 \pm 0.5^{\mathrm{c}}$ & $124 \pm 5^{\mathrm{c}}$ & $10.2 \pm 0.9^{\mathrm{c}}$ \\
\hline
\end{tabular}

Values are mean \pm SEM. Difference compared to vehicle of each column; ${ }^{\mathrm{a}} \mathrm{NS},{ }^{\mathrm{b}} \mathbf{P}<0.05,{ }^{\mathrm{c}} \mathrm{P}<0.001$. 


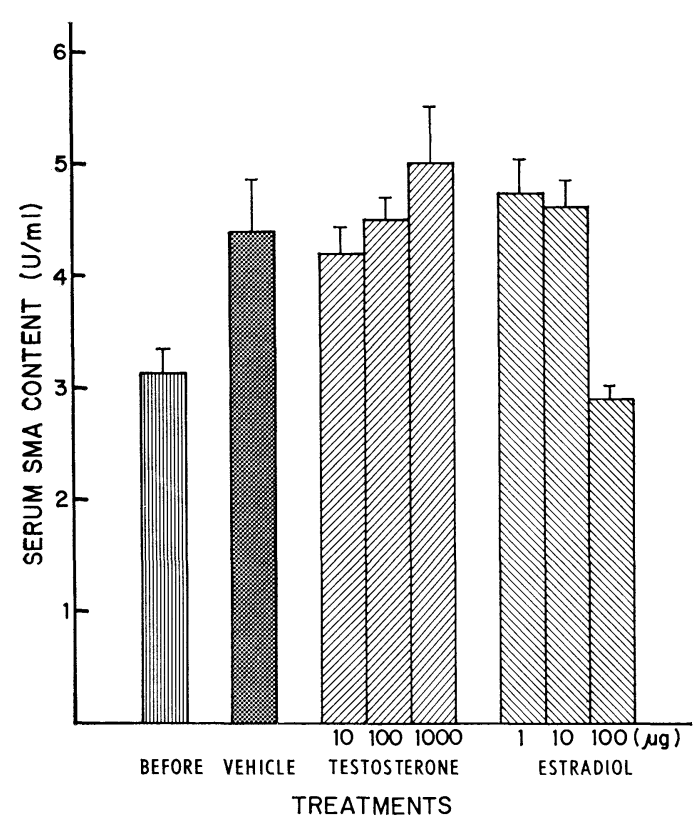

Fig. 3. Effect of various amounts of sex steroids on SMA content in normal rats. Values are mean \pm $\operatorname{SEM}(n=5)$.

$\mu \mathrm{g}$ or $100 \mu \mathrm{g} /$ day, alternately for 10 days) or $\mathrm{E}_{2}(1 \mu \mathrm{g}$ or $10 \mu \mathrm{g} / \mathrm{day}$, alternately for 10 days) did not affect the increase in serum SMA (Fig. 3) and growth rate during 10 days.

Effect of sex steroids on serum SMA and growth of gonadectomized male rats

To exclude the influence of endogenous testicular androgens in male rats, sex steroids were administered to gonadectomized rats whose testes were removed at 22 days. The administration of $\mathrm{E}_{2}$ suppressed the increase in the serum SMA. The increase in body weight and length tended to be suppressed as well (Table 2). The administration of $\mathrm{T}$ did not exhibit a significant effect on the increase in the serum SMA. However, the increase in body weight was larger than that of the vehicle group accompanying greater food intake (Table 2).

Effect of sex steroids on serum SMA and growth of female rats

In female rats, the administration of $\mathrm{T}$ did not affect the increase in the serum SMA but enhanced the increase in body length significantly. On the other hand, $E_{2}$ suppressed the increase in the serum SMA and food intake, although the growth was not retarded significantly (Table 3).

Effect of sex steroids on serum SMA and growth of hypox male rats

The serum SMA content of hypox male rats was low, as expected. The serum SMA of the hypox male rats increased with $\mathrm{E}_{2}$ and not with $T$. The body length and weight were not effected by $\mathrm{T}$ but was decreased significantly by $\mathrm{E}_{2}$ (Table 4 ).

When $0.2 \mathrm{U}$ of bGH was injected concurrently for 9 days, the serum SMA was higher in the rats with $\mathrm{T}$ than without. The body length and weight were highest in this group although the body length was not significantly greater than in the vehicle group. The serum SMA of the $\mathrm{E}_{2}$ group was the highest. Again,

Table 2. Effect of sex steroids on the growth of orchiectomized rat and serum SMA levels.

\begin{tabular}{lccccc}
\hline \multicolumn{1}{c}{ Groups } & No. & $\begin{array}{c}\text { SMA } \\
(\mathrm{U} / \mathrm{ml})\end{array}$ & $\begin{array}{c}\text { Body length } \\
(\mathrm{cm})\end{array}$ & $\begin{array}{c}\text { Body weight } \\
(\mathrm{g})\end{array}$ & $\begin{array}{l}\text { Food intake } \\
(\mathrm{g} / \mathrm{day} / \mathrm{rat})\end{array}$ \\
\hline Before & 4 & $4.47 \pm 0.47$ & $27.7 \pm 0.2$ & $126 \pm 4$ & $9.1 \pm 0.5$ \\
$\begin{array}{c}\text { Testosterone propionate } \\
(1 \mathrm{mg} / \text { day })\end{array}$ & 4 & $5.76 \pm 0.61^{\mathrm{a}}$ & $33.8 \pm 0.6^{\mathrm{a}}$ & $182 \pm 5^{\mathrm{b}}$ & $15.2 \pm 1.6^{\mathrm{c}}$ \\
$\begin{array}{l}\text { Estradiol benzoate } \\
(100 \mu \mathrm{g} / \text { day) } \\
\text { Vehicle }\end{array}$ & 4 & $3.84 \pm 0.31^{\mathrm{d}}$ & $30.8 \pm 0.5^{\mathrm{a}}$ & $143 \pm 8^{\mathrm{a}}$ & $12.2 \pm 1.7^{\mathrm{a}}$ \\
& 4 & $6.48 \pm 0.30$ & $32.1 \pm 0.7$ & $148 \pm 10$ & $11.8 \pm 0.4$ \\
\hline
\end{tabular}

Values are mean \pm SEM. Difference compared to vehicle of each column; ${ }^{a} \mathrm{NS},{ }^{\mathrm{b}} \mathrm{P}<0.05,{ }^{\mathrm{c}} \mathrm{P}<0.01$, ${ }^{\mathrm{d}} \mathbf{P}<.0001$. 
Table 3. Effect of sex steroids on the growth of female rats and serum SMA levels.

\begin{tabular}{lccccc}
\hline \hline \multicolumn{1}{c}{ Groups } & No. & $\begin{array}{c}\text { SMA } \\
(\mathrm{U} / \mathrm{ml})\end{array}$ & $\begin{array}{c}\text { Body length } \\
(\mathrm{cm})\end{array}$ & $\begin{array}{c}\text { Body weight } \\
(\mathrm{g})\end{array}$ & $\begin{array}{c}\text { Food intake } \\
(\mathrm{g} / \text { day/rat })\end{array}$ \\
\hline Before & 4 & $3.15 \pm 0.33$ & $27.0 \pm 0.4$ & $120 \pm 4$ & $11.2 \pm 1.3$ \\
$\begin{array}{l}\text { Testosterone propionate } \\
(1 \mathrm{mg} / \text { day })\end{array}$ & 4 & $4.53 \pm 0.57^{\mathrm{a}}$ & $31.7 \pm 0.3^{\mathrm{c}}$ & $154 \pm 9^{\mathrm{a}}$ & $12.6 \pm 0.6^{\mathrm{c}}$ \\
$\begin{array}{l}\text { Estradiol benzoate } \\
\quad(100 \mu \mathrm{g} / \text { day) }\end{array}$ & 4 & $2.87 \pm 0.22^{\mathrm{b}}$ & $30.3 \pm 0.4^{\mathrm{a}}$ & $133 \pm 7^{\mathrm{a}}$ & $11.1 \pm 1.4^{\mathrm{c}}$ \\
Vehicle & 4 & $4.72 \pm 0.57$ & $29.9 \pm 0.3$ & $145 \pm 2$ & $14.3 \pm 0.5$ \\
\hline
\end{tabular}

Values are mean \pm SEM. Difference compared to vehicle of each column; ${ }^{\mathrm{a}} \mathrm{NS},{ }^{\mathrm{b}} \mathrm{P}<0.05,{ }^{\mathrm{c}} \mathrm{P}<0.01$, ${ }^{\mathrm{d}} \mathbf{P}<0.005$.

Table 4. Effect of sex steroids on the growth of hypox or hypox rats concurrently treated with bGH (0.2 U, every day) and serum SMA levels.

\begin{tabular}{|c|c|c|c|c|c|}
\hline Groups & No. & $\begin{array}{l}\mathrm{SMA} \\
(\mathrm{U} / \mathrm{ml})\end{array}$ & $\begin{array}{l}\text { Body length } \\
(\mathrm{cm})\end{array}$ & $\begin{array}{l}\text { Body weight } \\
(\mathrm{g})\end{array}$ & $\begin{array}{l}\text { Food intake } \\
\text { (g/day/rat) }\end{array}$ \\
\hline Before & 4 & $1.13 \pm 0.04$ & $24.7 \pm 0.2$ & $82.0 \pm 1.4$ & $5.3 \pm 0.9$ \\
\hline $\begin{array}{l}\text { Testosterone propionate } \\
\text { ( } 1 \mathrm{mg} / \text { day })\end{array}$ & 4 & $0.75 \pm 0.07^{\mathrm{a}}$ & $25.4 \pm 0.5^{\mathrm{a}}$ & $89.5 \pm 4.2^{\mathrm{a}}$ & $6.4 \pm 0.5^{\mathrm{a}}$ \\
\hline$+\mathrm{bGH}$ & 4 & $1.65 \pm 0.01^{\mathrm{b}^{\prime}}$ & $27.3 \pm 0.5^{a^{\prime}}$ & $114.3 \pm 5.6^{\mathrm{d}^{\prime}}$ & $4.3 \pm 0.5^{3^{\prime}}$ \\
\hline $\begin{array}{l}\text { Estradiol benzoate } \\
\quad(100 \mu \mathrm{g} / \text { day })\end{array}$ & 4 & $2.37 \pm 0.31^{\mathrm{c}}$ & $23.7 \pm 0.3^{b}$ & $67.8 \pm 3.3^{\mathrm{c}}$ & $3.9 \pm 0.0^{\mathrm{e}}$ \\
\hline$+\mathrm{bGH}$ & 4 & $3.09 \pm 0.48^{\mathrm{d}^{\prime}}$ & $24.2 \pm 0.2^{\mathrm{d}^{\prime}}$ & $75.3 \pm 4.3^{\mathrm{d}^{\prime}}$ & $1.7 \pm 0.7^{e^{\prime}}$ \\
\hline Vehicle & 4 & $0.77 \pm 0.03$ & $26.3 \pm 0.6$ & $90.8 \pm 3.0$ & $6.3 \pm 0.3$ \\
\hline$+\mathrm{bGH}$ & 4 & $1.46 \pm 0.01$ & $27.1 \pm 0.5$ & $103.8 \pm 2.5$ & $7.2 \pm 0.8$ \\
\hline
\end{tabular}

Values are mean \pm SEM. Difference compared to vehicle of each column; ${ }^{\mathrm{a}} \mathrm{NS},{ }^{\mathrm{b}} \mathbf{P}<0.05,{ }^{\mathrm{c}} \mathbf{P}<0.01,{ }^{\mathrm{d}} \mathbf{P}<$

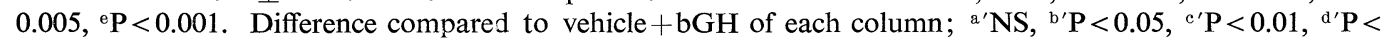
$0.005,{ }^{\mathrm{e}} \mathrm{P}<0.001$.

Table 5. Sulfation activity of the serum from male normal, hypox and hypox $+\mathrm{bGH}$ rats injected sex steriods.

\begin{tabular}{|c|c|c|c|c|c|c|}
\hline \multirow[b]{2}{*}{ Groups } & \multicolumn{2}{|c|}{ Normal } & \multicolumn{2}{|c|}{ Hypox } & \multicolumn{2}{|c|}{ Hypox + bGH } \\
\hline & $\begin{array}{c}\text { Sulfation } \\
\text { activity } \\
(\mathrm{U} / \mathrm{ml})\end{array}$ & $\begin{array}{c}\text { SMA } \\
\text { level } \\
(\mathrm{U} / \mathrm{ml})\end{array}$ & $\begin{array}{c}\text { Sulfation } \\
\text { activity } \\
(\mathrm{U} / \mathrm{ml})\end{array}$ & $\begin{array}{c}\text { SMA } \\
\text { level } \\
(\mathrm{U} / \mathrm{ml})\end{array}$ & $\begin{array}{c}\text { Sulfation } \\
\text { activity } \\
(\mathrm{U} / \mathrm{ml})\end{array}$ & $\begin{array}{c}\text { SMA } \\
\text { level } \\
(\mathrm{U} / \mathrm{ml})\end{array}$ \\
\hline Bcfore & 1.18 & 2.53 & $0.28^{*}$ & 1.13 & $0.28^{*}$ & 1.13 \\
\hline $\begin{array}{l}\text { Testosterone propionate } \\
(1 \mathrm{mg} / \text { day })\end{array}$ & 1.29 & 4.99 & $0.31^{*}$ & 0.72 & 0.63 & 1.48 \\
\hline $\begin{array}{l}\text { Estradiol benzoate } \\
\quad(100 \mu \mathrm{g} / \text { day })\end{array}$ & 0.98 & 2.85 & $0.28 *$ & 2.68 & $0.13^{*}$ & 3.31 \\
\hline Vehicle & 1.27 & 4.24 & $0.26^{*}$ & 0.76 & 0.68 & 1.44 \\
\hline
\end{tabular}

Sulfation activity and SMA level (by RRA) of pooled sera used in the experiments shown in Table 1 and 4 were measured as described in Materials and Methods. *Values estimated graphically.

the increase in body weight and length were considerably suppressed. The food intake of this group was extremely reduced.

\section{Sulfation activity of the rat serum}

In the hypox rats treated $E_{2}$, the elevated serum SMA was not accompanied by an increase in the growth rate. Therefore, the bio-activity of somatomedins in the serum 
Table 6. Effect of sex steroid on ${ }^{35} \mathrm{~S}$ incorporation into embryonic chick cartilage.

\begin{tabular}{lccc}
\hline \multirow{2}{*}{$\begin{array}{c}\text { Hormone } \\
\text { added }\end{array}$} & $\begin{array}{c}\text { Final } \\
\text { concentrations }\end{array}$ & $\begin{array}{c}\text { Incorporation of }{ }^{35} \mathrm{SO}_{4}(\% \text { of vehicle }) \\
\text { without normal } \\
\text { human serum }\end{array}$ & $\begin{array}{c}\text { with } 25 \% \text { normal } \\
\text { human serum }\end{array}$ \\
\hline $0.008 \%$ Ethanol (Vehicle) & & $100 \pm 8.0$ & $100 \pm 14.0$ \\
Testosterone propionate & $2.5 \mathrm{ng} / \mathrm{ml}$ & $106 \pm 5.8$ & $101 \pm 7.8$ \\
& 25 & $99 \pm 7.7$ & $95 \pm 2.7$ \\
& 250 & $72 \pm 3.7^{\mathrm{b}}$ & $111 \pm 8.1$ \\
Estradiol benzoate & $5 \mathrm{pg} / \mathrm{ml}$ & $101 \pm 4.8$ & $104 \pm 13.4$ \\
& 50 & $114 \pm 6.7^{\text {a }}$ & $106 \pm 14.2$ \\
$\mathrm{H}_{2} \mathrm{O}$ & 500 & $92 \pm 7.5$ & $121 \pm 11.9^{\mathrm{a}}$ \\
\end{tabular}

$\mathrm{T}$ and $\mathrm{E}_{2}$ were dissolved with ethanol and added to the assay mixture. Their vehicle (finally $0.008 \%$ ethanol) had no effect on the sulfation activity by itself. Values are mean \pm SEM. Difference compared to vehicle; ${ }^{\mathrm{a}} \mathrm{NS},{ }^{\mathrm{b}} \mathrm{P}<0.02$.

was assayed by ${ }^{35} \mathrm{~S}$ incorporation into embryonic chick pelvic cartilage. Table 5 shows that the biological potency in hypox rat serum of $\mathrm{E}_{2}$ group was very low. It remained low after concurrent injection of bGH. It is also shown that the sulfation activity of normal male rat serum was nearly the same as that of the normal human serum. This is in contrast to the observation that the value measured by RRA was significantly higher in the rat than that in the human serum.

Effect of sex steroids on ${ }^{35} S$ incorporation into embryonic chick cartilage

The direct effect of sex steroids on sulfation activity by serum somatomedins was examined. Although a very high concentration of $\mathrm{T}$ (250 $\mathrm{ng} / \mathrm{ml}$ ) inhibited ${ }^{35} \mathrm{~S}$ incorporation into embryonic chick pelvic cartilage in the absence of serum somatomedins, physiological doses of $T$ or $E_{2}$ did not affect the sulfation activity either in the presence or absence of serum in vitro (Table 6).

\section{Discussion}

The present study showed that the serum SMA level clearly increased in parallel with the pubertal growth spurt (Fig. 2). Testo- sterone caused a significant acceleration of the increase in body weight of gonadectomized male rats and body length of normal female rats without a change in the serum SMA level (Table 2 and 3). Testosterone did not exhibit any effect on growth or the serum SMA level in hypox male rats, while it significantly augumented the increase in body weight and serum SMA level in hypox male rats supplemented with bGH (Table 4). These results are in line with the earlier observations that $\mathrm{T}$ stimulated the sulfate uptake into costal cartilages of castrated rats with intact pituitary (Salmon et al., 1963) and that the administration of $\mathrm{T}$ to hypox male or female rats supplemented by bGH caused an increase in the thymidine uptake in the cartilages (Matsuzaki, 1974). From these results it seems almost certain that testosterone or its metabolites exhibits a growth stimulating activity in vivo in a manner dependent on the presence of $\mathrm{GH}$. In the in vitro system, testosterone did not activate sulfate incorporation by chick cartilage either in the presence or absence of the serum. Phillips et al. (1975) reported the same results. The effect of androgens on growth hormone synthesis and secretion is controversial (Hang and Gautvik, 1978). In rats no difference was found between the prepubertal and the pubertal levels of daily 
GH secretion (Thompson et al., 1972 and Plotnick et al., 1974). These data and the present results indicate that the growth promoting effect of testosterone evolves through the production of SMA via a GH dependent reaction under subnormal $\mathrm{GH}$ secretion, and that testosterone potentiates the effect of SMA which is not able to be elucidated by its sulfation activity in vitro.

The serum SMA of group 1 (before) of gonadectomized rats was higher than that of group 1 of normal male rats (Table 1 and 2). In the subsequent repetitive type of experiments, the serum SMA level of 30 days orchiectomized rat was $4.09 \mathrm{U} / \mathrm{ml}$, that of sham operation $4.31 \mathrm{U} / \mathrm{ml}$ and that of nontreatment $3.82 \mathrm{U} / \mathrm{ml}$. Thus it was concluded that the difference was due to the difference in animal batches rather than to the effect of gonadectomy.

The administration of $E_{2}$ to normal rats lowered the serum SMA level (Table 1). $E_{2}$ exhibited no effect on sulfate incorporation by cartilage in vitro (Table 6). These results are compatible with the previous reports by Wiedemann and Schwarz (1972) and Phillips et al. $(1974,1975)$. They showed that the administration of $E_{2}$ lowered the level of serum somatomedin activity of hypox rat treated concurrently with bGH. They also showed that in a patient with acromegaly a short term estrogen therapy (7-18 days) caused a prompt reduction in the elevated sulfation factor without affecting the plasma growth hormone levels and that $\mathrm{E}_{2}(0.1-100 \mathrm{ng} / \mathrm{ml})$ in vitro had no effect upon the bioassay system of sulfation factors. Food intake was significantly suppressed by $E_{2}$. Malnutrition maybe partly contribute to the reduced increase in growth and serum SMA level reported by Takano et al. (1978).

In this study, it was recognized that serum SMA levels of normal male rats measured by RRA were about 5 times as high as those of normal adult men and increased further with aging (Fig. 2). The sulfation potency of these rat sera were almost the same as that of the human serum (Table 5). The serum sulfate was about 3 times higher in rat than in man $(95.7 \mu \mathrm{g} / \mathrm{ml}$ and $35.1 \mu \mathrm{g} / \mathrm{ml}$, respectively, by the method of Kleeman et al., 1956). Thus, the specific activity of ${ }^{35} \mathrm{SO}_{4}$ is diluted only by a factor of 1.43. Therefore, reasons other than the contamination of cold sulfate should be considered. Although the binding of somatomedin A to its receptor on the placental membrane is very specific (Takano et al., 1975), it might be due to the existence of somatomedins without sulfation potency which retain binding capacity to the somatomedin receptor on human placenta. It was already clarified that somatomedin $\mathrm{C}$, insulin like growth factors I and II, and multiplication stimulating activity displace ${ }^{125} \mathrm{I}$-labeled SMA on the placental receptor (Hall et al., 1978). However, their sulfation potency in chick cartilage was not fully demonstrated. The existence of SMA without sulfation activity was further suggested by the result that serum SMA in hypox rats injected with $E_{2}$ was significantly higher than the other groups but that their growth was extremely retarded (Table 5).

Thus it has become evident that gonadal steroids are intimately involved in the regulation of pubertal growth spurt. Although both androgens and estrogens exhibited their effects in a GH dependent manner, analyses of serum SMA by RRA as compared with serum somatomedins-level obtained by the sulfation activity indicate the multiplicities of $\mathrm{GH}$ dependent growth factors induced by the steroids and effector sites of steroid hormones; the steroids appear to act at the level of somatomedin production and somatomedin function.

\section{Acknowledgement}

The authors are greatly indebted to Doctors Linda Fryklund and Hans Sievertsson from the Research Department of AB Kabi, Stockholm, who purified and supplied us with the somatomedin A preparations used in this experiment. We wish to thank Mrs. M. Yoshida for her expert technical assistance. This report was partly supported by a Research Grant from Foundation 
for Growth Science (Japan) and from the Ministry of Education, Science and Culture, Japan.

\section{References}

Almqvist S., D. Ikkos and R. Luft (1961). Studies on sulfation factor (SF) activity of human serum: The effects of oestrogen and X-ray therapy on serum SF activity in acromegaly. Acta Endocrinol. (Kbh.) 37, 138-147.

Berntsen, E. (1968). Epiphyseal growth zones in oestradiol treated rabbits. Acta Endocrinol. (Kbh.) 57, 69-80.

Daughaday, W. H., K. Hall, M. S. Raben, W. D. Salmon, J. L. Van den Brande and J. J. Van WyK (1972). Somatomedin: A proposed designation for the "sulfation factor". Nature 235, 107.

Daughaday, W. H., A. C. Herington and L. S. Phillips (1975). The regulation of growth by endocrines. An. Rev. Physiol. 37, 211-244.

Eisenbarth, G. S., S. C. Beuttel and H. E. Lebovitz (1973). Fatty acid inhibition of somatomedin (serum sulfation factor) stimulated protein and RNA synthesis in embryonic chicken cartilage. Biochim. Biophys. Acta 331, 397-409.

Geschwind, I. I. and C. H. Li. (1955). The tibia test for growth hormone. In: The Hypophyseal Growth Hormone, Nature and Actions (R. W. Smith Jr., O. H. Goebler and C. N. H. Long eds.), McGraw, New York. pp. 28-53.

Hall, K. (1970). Quantative determination of the sulfation factor activity in human serum. Acta Endocrinol. (Kbh.) 63, 338-350.

Hall, K., L. Fryklund, H. Löw, A. Skottner and R. Zederman (1978). Receptor binding and biological effects of somatomedin A in vitro. In: Growth Factors; Remove Federation of European Biochemical Societies 11th Meeting, Copenhagen 1977 (K. W. Kastrup and J. H. Nielsen eds.) Pergamon, Oxford and New York. pp. 59-64

Hang, E. and K. M. Gautvik (1978). Effects of sex steroids on growth hormone production in cultured rat pituitary cells. Acta Endocrinol. (Kbh.) 87, 4054.

Kawai, K. and E. Ogata (1981). The role of $\mathrm{Ca}^{++}$ in sulfation factor activity on embryonic chick cartilage. Metabolism 30, 761-764.

Kleeman, C. R., E. Taborsky and F. H. Epsterin (1956). Improved method for determination of inorganic sulfate in biologic fluids. Proc. Soc. Exp. Biol. Med. 91, 480-483.

Matuzaki, F. (1974). Somatomedin. In: Pituitary; Proceedings of 4th Kawaguchi Lake Conference $(H$. Imura and K. Miyai eds.) Ishiyaku shuppan, Tokyo, pp. 216-241. (In Japanese).

Phillips, L. C., A. C. Herington and W. H. Daughaday (1974). Hormone effects on somatomedin action and somatomedin generation. In: Advances in Human Growth Hormone Research, Proc. Symp. Nat. Pituitary Agency, NIAMDD, 1973, Baltimore (S. Raiti ed.) DHEW Pub (NIH), pp. 50-75.

Phillips, L. S., A. C. Herington and W. H. Daughaday (1975). Steroid hormone effects on somatomedin. I. Somatomedin action in vitro. Endocrinology 97, 780-786.

Plotnick, L. P., R. G. Thompson, I. Beitins and R. M. Blizzard (1974). Integrated concentrations of growth hormone correlated with stage of puberty and estrogen levels in girls. J. Clin. Endocrinol. Metab. 38, 436-439.

Salmon, W. D., Jr., P. H. Bower and E. Y. Thompson (1963). Effect of protein anabolic steroids on sulfate incorporation by cartilage of male rats. $J$. Lab. Clin. Med. 61, 120-128.

Takano, K., K. Hall, L. Fryklund, A. Holmgren, H. Sievertsson and $\mathbf{X}$. Uthne (1975). The binding of insulin and somatomedin A to human placental membrane. Acta Endocrinol. (Kbh.) 80, 1-18.

Takano, K., N. Hizuka, K. Kawai and K. Shizume (1978). Effect of growth hormone and nutrition on the level of somatomedin A in the rat. Acta Endocrinol. (Kbh.) 87, 485-494.

Thompson, R. G., A. Rodriguez, A. Kowarski, C. J. Migeon and R. M. Blizzard (1972). Integrated concentrations of growth hormone correlated with plasma testosterone and bone age in preadolescent and adolescent males. J. Clin. Endocrinol. Metab. 35, 334-337.

Wiedemann, E. and E. Schwartz (1972). Suppression of growth hormone-dependent human serum sulfation factor by estrogen. J. Clin. Endocrinol. Metab. $34,51-58$. 